\title{
Green desert or 'all you can eat'? How diverse and edible was the flora of Vanuatu before human introductions?
}

\author{
Vincent Lebot and Chanel Sam
}

\begin{abstract}
The islands of Vanuatu are relatively young geologically, having been formed through tectonic activity. They were colonised very early after their formation by plant species that have come from three main sources (northern Melanesia, New Caledonia and Fiji), carried by winds, ocean currents, birds and bats. When Lapita people arrived, they most likely found edible species there. This paper attempts to understand how settlers could have diversified their diets with plants collected directly from the local flora. Although this flora is considered rather poor compared to the three main source regions, this paper outlines how these colonising settlers could have foraged for local species whose leaves, fruits and tubers could have been eaten readily upon arrival, providing support for their subsistence during initial settlement. Different approaches will be considered to clarify the debate over Early Lapita diets in Remote Oceania.
\end{abstract}

\section{Introduction}

The three different island chains that compose the Vanuatu archipelago vary in age from 20 million years old for the western chain, five million years old for the eastern chain and to two million years old for the central chain where volcanoes are still active (Carney et al. 1985; Greene and Wong 1988; Hamilton et al. 2010; Monzier et al. 1997). The local flora was established from three major sources: the Solomon Islands in the north, Fiji in the east and New Caledonia in the south (Mueller-Dombois and Fosberg 1998). These three sources are considered very rich and diversified botanically because of their ancient continental origins. Plants used different means to reach the islands of Vanuatu — winds, sea currents, birds or bats—and plant species established themselves naturally over millions of years. The arrival of predators (humans, rats, pigs and possibly dogs) is, in comparison, a very recent phenomenon that occurred only around 3000 years ago (Bedford 2006; Petchey et al. 2014). 
In the Pacific, the number of seed plant genera decreases with island area and distance from New Guinea and the continental island of New Caledonia (Keppel et al. 2009). As one moves away from continental sources, Pacific islands have lower species diversity. The dramatic decline in diversity between the ancient and large islands of the Solomons and smaller and younger islands of Vanuatu has encouraged archaeologists to suggest that beyond the Solomon Islands chain, the resources available to sustain populations fell off sharply (Green 1991). It has been seen as one possible reason that Pre-Lapita settlement did not happen in Remote Oceania and it inspired the term 'green desert' to qualify isolated islands such as Vanuatu (Spriggs 1997:41). Recent studies conducted on the Teouma Lapita site of Efate Island, Central Vanuatu, have, however, indicated that Lapita diet was probably based on a broad spectrum of foraging that does not exclude the possibility of eating locally found plant species (Kinaston et al. 2014). How far plant species have spread into the Pacific depends on their dispersal abilities and on the ecology of the colonised islands. Coastal taxa are often well dispersed by flotation or rafting propagules and this dispersal ability has resulted in many species, including edible ones, becoming naturally pan-tropical (Fosberg 1984).

When Lapita people first settled these islands, coming from the north, they most likely introduced with them their major staple crops: bananas (Musa spp.), the greater yam (Dioscorea alata) and taro (Colocasia esculenta), along with other crops (Abelmoschus manihot, Alocasia macrorrhizos, Saccharum spp.) (Walter and Lebot 2007). As these species have been asexually propagated since their ancient domestication further north in Melanesia (Lebot 1999), they were introduced in Vanuatu as vegetative propagules on voyaging canoes, just like elsewhere in Remote Oceania (McClatchey 2012; Whistler 2009). This was a rather complex operation, as these propagules are highly sensitive to salt sprays and drought. Their successful establishment after arrival was most likely the object of great and delicate attention. Their vegetative propagation ratios being very low, several years, maybe even a decade, were necessary before a sufficient stock could be established to feed a small community and reach full carrying capacity, assuming that natural disasters (cyclones or drought) did not complicate this complex and risky task.

There is now significant molecular evidence to confirm that the genetic bases of these staple crops are extremely narrow in Vanuatu, compared to the allelic diversity found further north for these species. Genetic diversity studies, conducted with isozymes and/or DNA markers (SSRs, AFLPs, DArTs), demonstrate that very few genotypes were introduced clonally. Most varieties found today are either: i) somatic mutants (sports) captured by cloning morphological variants while propagating mother plants; or ii) result from the selection of volunteers germinating in garden plots after cross-pollination and sexual recombination between parents genetically closely related. This is the case for yam (D. alata) (Lebot et al. 1998; Malapa et al. 2005; VandenBroucke et al. 2016), taro (C. esculenta) (Kreike et al. 2004; Lebot et al. 2004; Sardos et al. 2012) and bananas (Musa spp.) (Lebot et al. 1993). These corroborating results indicate very few clonal introductions on canoes, from an already narrow gene pool, and the same bottleneck process also occurred further east in Polynesia (Lebot 1992). These molecular studies confirm that the propagation of the germplasm necessary for feeding important communities was obviously a very slow process that took decades, if not hundreds of years, before all the main islands of Vanuatu could be densely populated.

Recent archaeological data have shown that the first settlers' diets were mostly protein-based and poorly diversified (Kinaston et al. 2014). The study of skeletal lesions in infants and adults at the Teouma Lapita site on Efate indicated that these communities may have been suffering from scurvy (Buckley et al. 2014). These observations revealed nutritional deficiencies during the colonisation phase of Vanuatu (c. 3000 years ago) and would tend to suggest two possibilities. The first scenario is that the archipelago was a 'green desert' at that time and that the absence 
of edible species had a serious impact on human health, as suggested by Buckley et al. (2014). This also implies that as the major food crops (bananas, taro and yam) are mostly carbohydrates (starch represents between 70 and 90 per cent of the dry matter) rather than sources of vitamins, proteins and minerals, many other edible plants would have been introduced from the north before well-balanced diets could be achieved. The second scenario would be that first settlers' unbalanced diets indicate that they did not exploit the potential of the local flora. Such behaviour could be driven by cultural traits: poor knowledge of the local flora (even if many species are similar than those found in the Solomon Islands), unwillingness to explore the inland forests of the new islands, and ease of collecting on the shores the necessary protein through fishing and hunting thanks to the abundance of rich wild resources (marine and terrestrial) (e.g. White et al. 2010; Worthy et al. 2015).

Consequently, this raises the question of the edibility of the native plant species (those naturally established before the arrival of humans) around 3000 years ago in Vanuatu. In the present paper we will attempt to identify native edible species from the Vanuatu National Herbarium collection and will discuss their possible use as sources of essential nutrients.

\section{Materials and methods}

The Port Vila National Herbarium (international code: PVNH) is managed by the Department of Forestry, at Tagabe, in Port Vila (www.forestry.gov.vu/). Approximately 20000 specimens are preserved and more than 14000 are recorded in a database along with their relevant passport data (publish.plantnet-project.org/project/vanuaflora_en/collection/pvnh/specimens). The first specimens were collected during the Condominium era and given back (to PVNH) in 1971 by the Royal Society. Since that time, numerous collections have been made by botanists from different countries. In the 1980s, ORSTOM (Office de la Recherche Scientifique et Technique d'Outre-Mer), today named IRD (Institut de Recherches pour le Développement), formalised the organisation and management of the herbarium and transferred PVNH to the Government of Vanuatu in 1988. More recently, an updated database, named 'Vanuaflora', was designed with Pl@ntNote (amap-collaboratif.cirad.fr/pages-logiciels/?page_id=410) and enriched with voucher specimens retrieved from the New Caledonia Herbarium in Nouméa.

A total of 1586 species of vascular plants have been collected and identified; 1166 species are considered to be natives (73 per cent of total spp.) and represent 550 genera assembled in 166 families. In order to assess if a species is truly native, different approaches are usually combined. A species is considered 'native' if its presence is the result of only natural processes with no human intervention. Its introduction to the Vanuatu archipelago has, therefore, to result from: flotation and drifting across the ocean (hydrochory), internal animal dispersal (endozoochory), external animal dispersal (epizoochory), bats (chiropterochory), birds (ornithochory) or wind (anemochory). This can be confirmed by the species biogeography and the study of related species (from the same genus) in the three regional sources nearby (Solomon Islands, Fiji and New Caledonia). Observations on the ecology of the plant recorded when collecting the specimen individual are also used to clarify if the species is self-adapted or self-seeded, easily spread by local vectors and well-distributed spatially (throughout Vanuatu, indicating an old natural introduction). Finally, balanced sex ratios (for dioecious species), pollen fertility and genetic evidence for true natural populations, revealed by molecular markers, are also used when available. These different approaches are combined to extract (in an Excel spreadsheet) a list of native species. Local knowledge recorded in situ at the time of voucher collection is then used to confirm if the useful plant organs can be eaten raw or if cooking techniques are needed before consumption. 


\section{Results}

Native edible plant species can be classified into five groups: fruits, nuts, leaves, palm hearts, and roots and tubers (Table 19.1). Fleshy fruited species are very diverse and most likely represented wild food resources readily available upon arrival. The coconut (Cocos nucifera) was of course on the shores before people arrived (Spriggs 1984), as were many Pandanus and Freycinetia species with tasty edible fleshes, rich in starch and juice (Walter and Lebot 2007). Many of these fruit species were disseminated by bats, birds or ocean currents and reproduce spontaneously in the wild (Wheatley 1992). They are also geographically widespread, with some morphotypes being better adapted in the south rather than in the north of the archipelago, others on the windward rather than the leeward sides of a given island. Numerous distinct morphotypes exist within each species, indicating their ancestry and their genetic variation (Lebot et al. 2007). Harvest is often opportunistic as the fruiting season can be quite short. Some are very tall trees producing hundreds of kilograms of fruit with high vitamin $\mathrm{C}$ content when mature (e.g. Dracontomelon vitiense, $28 \mathrm{mg}$ per $100 \mathrm{~g}$ edible portion). Most figs (Ficus spp.) are also very rich in vitamin $\mathrm{C}$, with content up to $72 \mathrm{mg}$ per $100 \mathrm{~g}$ of edible portion (English et al. 1996) (Figure 19.1).

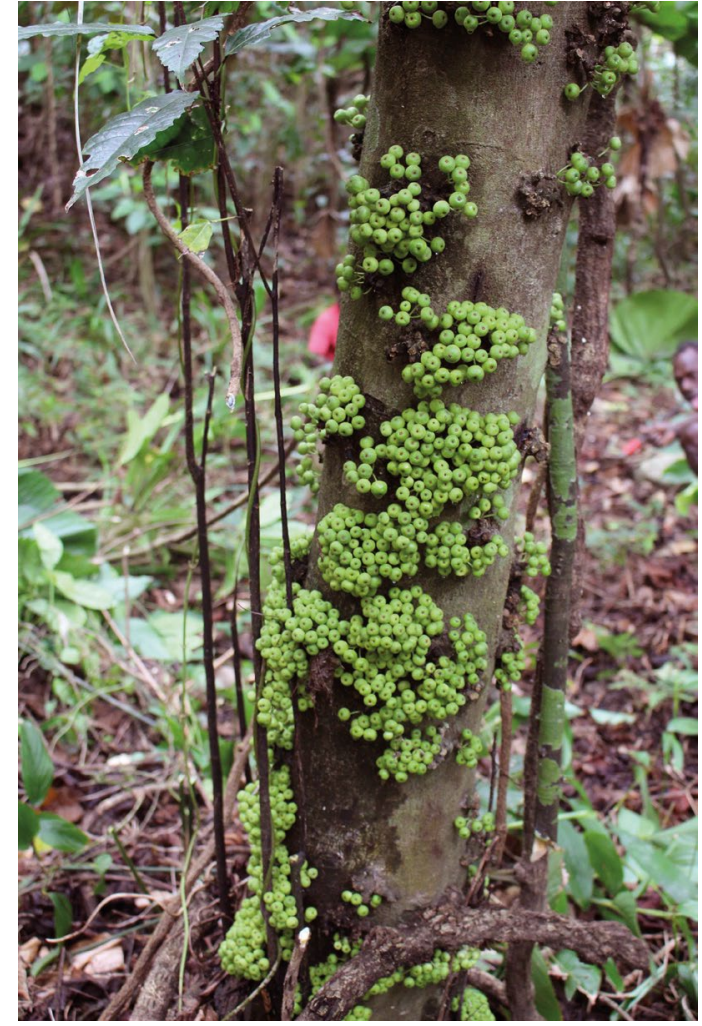

Figure 19.1. Ficus wassa.

This wild tree is never cultivated, it is very vigorous and easily dispersed by birds. The figs can be boiled in bamboo containers when they are green. They become rosy and red at maturity and can be eaten raw. It is available throughout the year. Young leaves are also eaten.

Source: Stuart Bedford.

Tremendous intra-specific variation exists for nut species as well, and some of them are dioecious and highly heterozygous. Canarium species and several other fruit trees are often considered to have been domesticated elsewhere in Near Oceania and humanly transported (Yen 1974). However, close observation of their fruits and kernels reveals that they can disperse easily through flotation or on drifting rafts, and there is evidence to favour their natural establishment on the Vanuatu islands before the arrival of humans. Canarium harveyi exists naturally only in the Solomons, Vanuatu and Fiji. It is found on all the islands of Vanuatu and nowadays numerous wild trees can be observed in undisturbed habitats such as the forests of central Erromango (Wheatley 1992). There are several botanical varieties of $C$. harveyi but two are found only in Vanuatu: $C$. harveyi var. nova hebridense in the north (Banks archipelago) and $C$. harveyi var. harveyi in Erromango. Distinctions are made mostly on the shape of their nut (var. harveyi has a triangular section while var. nova hebridense has three dorsal and one ventral crests). As Canarium spp. are large, slow-growing dioecious trees within the wild, such morphological differentiation reveals a very ancient establishment of natural populations. Canarium indicum also shows great variability in Vanuatu. The variation includes the shape of the fruit but also the number of kernels in a shell, their colour, the rhythm of flowering, the productivity and the ease of cracking the nuts. The species is more frequent in the northern part of Vanuatu, becoming rarer in the southern 
part. In Vanuatu, Canarium spp. found in the wild are highly heterozygous, with some nuts so rich in polyphenols (with a turpentine-like distinctive smell) that it is better to avoid them. Most of these nuts are very rich in fat (11 to $40 \mathrm{~g}$ per $100 \mathrm{~g}$ of edible portion) and proteins (8 to 12 per cent) (English et al. 1996).

Most ferns have edible young leaves and all native palm species produce long cylindrical hearts, easily accessible when the plants are still young (Figure 19.2). Although they are poor in dry matter (90 per cent water), they represent a good source of minerals. Some palms (such as Veitchia sp.) also produce dense clusters of fruits, which are eaten when immature and soft and are rich in minerals.

Three yam species (Dioscorea bulbifera, D. nummularia and D. pentaphylla) grow wild in Vanuatu. A fourth one (D. hebridensis) has been identified but seems to be a variant morphotype of spontaneous $D$. nummularia wild forms. All three species produce numerous seeds adapted to wind dispersion. Important natural populations have most likely been destroyed by pigs, which can easily uproot their superficial tubers. However, in favourable but isolated areas (like south-east Ambrym or on the now-unpopulated Lopevi Island), it is still possible to find in the forest numerous individuals of wild $D$. nummularia. Their tubers are often very thin and long (about 3 to $5 \mathrm{~cm}$ in diameter), very superficial and do not require detoxification (Figure 19.3). They can be readily roasted on a fire and are very rich in starch (80-92 per cent of dry matter). On the other hand, wild forms of D. bulbifera and $D$. pentaphylla often necessitate detoxification via cooking to remove the bitterness (alkaloids and polyphenols). They are, however, easily accessible and convenient sources of energy, just like Pueraria lobata, when cyclones have damaged wild fruit and nut trees species.

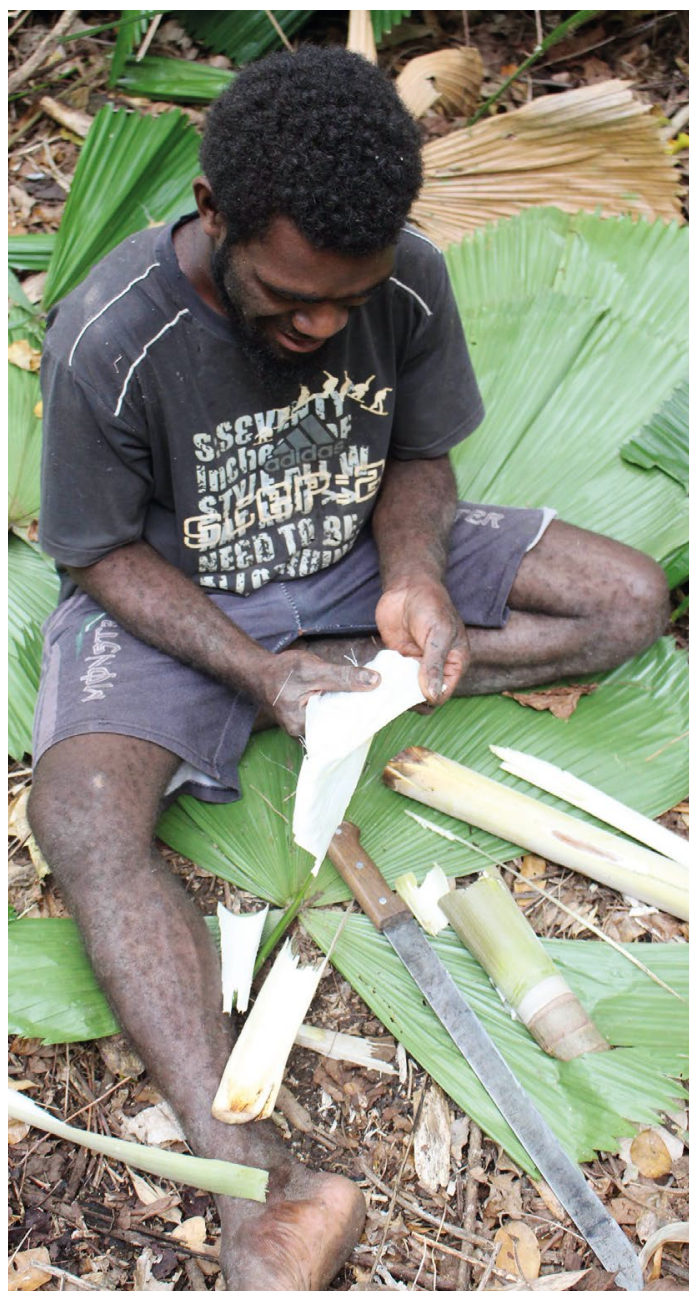

Figure 19.2. Licuala grandis.

This is a shade-loving small palm (3-6 m) growing wild under the canopy of taller trees and very frequent throughout the islands of Vanuatu. The heart is easily accessible and can be eaten raw. It is very tasty and refreshing and is appreciated by hunters having to spend some time in the forest.

Source: Stuart Bedford. 


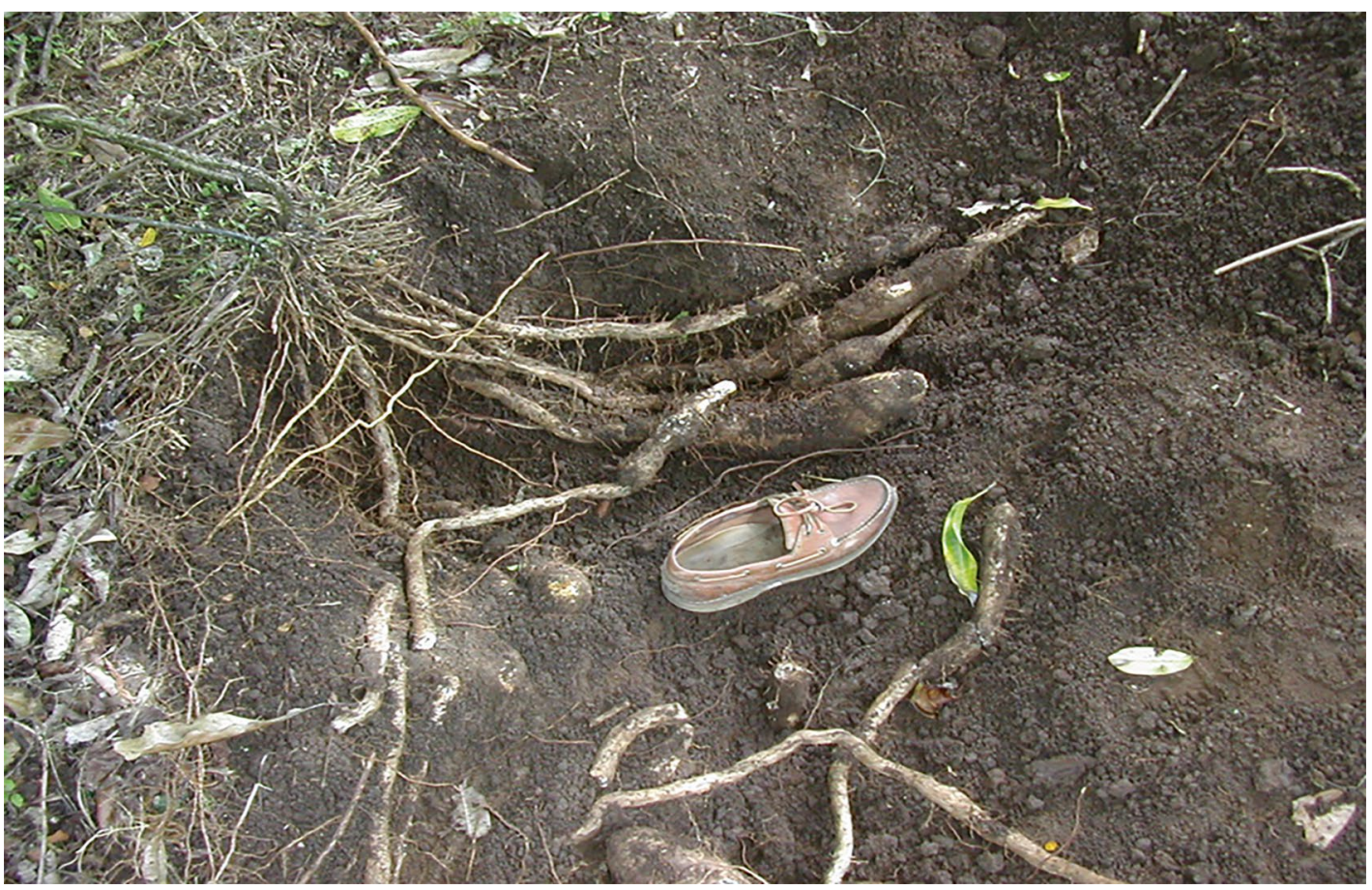

Figure 19.3. Wild yam (Dioscorea nummularia) populations were most likely devastated by the arrival of predators such as humans and pigs, looking for an easily accessible source of starch. The tubers can be roasted on a fire and do not need detoxification.

Source: Photo Vincent Lebot.

Although they are not covered in the present study, seaweeds deserve at least a mention as they are nutritionally important. Seaweed harvesting is usually combined with reef gleaning and collection of shellfish. The common edible seaweed (Caulerpa racemosa) is pantropical and widely distributed along the shores of the archipelago. Other edible species exist such as Acathophora spicifera, Gracilaria verrucosa and Hypnea pannosa. These seaweeds can be eaten raw and are a rich source of vitamins and minerals. The algal flora species of Vanuatu belong to the Indo-Pacific biogeographic province and 55 per cent of the species present in Santo are in the Solomon Islands (Payri 2011), suggesting that the new settlers would have recognised them as a convenient source of food upon arrival.

Table 19.1. List and distribution of wild edible food species in Vanuatu (PVNH specimens).

\begin{tabular}{|l|l|l|l|l|}
\hline Genus & Species & Family & Type & Main part consumed* \\
\hline Antidesma & sp. & Euphorbiaceae & tree & fruit \\
\hline Bruguiera & gymnorrhriza & Rhizophoraceae & tree & fruit \\
\hline Burckella & obovata & Sapotaceae & tree & fruit \\
\hline Claoxylon & sp. & Euphorbiaceae & tree & fruit \\
\hline Corynocarpus & similis & Corynocarpaceae & tree & fruit \\
\hline Corynocarpus & sp. & Corynocarpaceae & tree & fruit \\
\hline Dracontemelon & vitiense & Anacardiaceae & tree & fruit \\
\hline Ficus & adenosperma & Moraceae & tree & fruit \\
\hline Ficus & austrina & Moraceae & tree & fruit \\
\hline Ficus & glandifera & Moraceae & tree & fruit \\
\hline Ficus & granatum & Moraceae & tree & fruit \\
\hline Ficus & microcarpus & Moraceae & tree & fruit \\
\hline Ficus & obliqua & Moraceae & tree & fruit \\
\hline
\end{tabular}




\begin{tabular}{|c|c|c|c|c|}
\hline Genus & Species & Family & Type & Main part consumed" \\
\hline Ficus & prolixa & Moraceae & tree & fruit \\
\hline Ficus & scabra & Moraceae & tree & fruit \\
\hline Ficus & septica & Moraceae & tree & fruit \\
\hline Ficus & smithii & Moraceде & tree & fruit \\
\hline Ficus & storckii & Moraceae & tree & fruit \\
\hline Ficus & subcordata & Moraceae & tree & fruit \\
\hline Ficus & tinctoria & Moraceae & tree & fruit \\
\hline Ficus & virens & Moraceae & tree & fruit \\
\hline Ficus & virgata & Moraceae & tree & fruit \\
\hline Ficus & wassa & Moraceae & tree & fruit \\
\hline Hornstedtia & scottiana & Zingiberaceае & tree & fruit \\
\hline Ilex & vitiensis & Aquifoliaceae & tree & fruit \\
\hline Inocarpus & edulis & Fabaceae & tree & fruit \\
\hline Maеsa & spp. & Primulariaceae & tree & fruit \\
\hline Pandanus & compressus & Pandanaceəe & pandanus & fruit \\
\hline Pandanus & halleorum & Pandanaceae & pandanus & fruit \\
\hline Pandanus & tectorius & Pandanaceae & pandanus & fruit \\
\hline Phyllanthus & ciccoides & Phyllanthaceae & tree & fruit \\
\hline Planchonella & obovoidea & Sapotaceae & tree & fruit \\
\hline Pometia & pinnata & Sapindaceae & tree & fruit \\
\hline Pongamia & pinnata & Fabaceae & tree & fruit \\
\hline Pouteria & Spp. & Sapotaceәе & tree & fruit \\
\hline Pterocarpus & indicus & Fabaceae & tree & fruit \\
\hline Schefflera & actinostigma & Araliaceae & tree & fruit \\
\hline Solanum & repandum & Solanaceae & shrub & fruit \\
\hline Spondias & cythera & Anacardiaceae & tree & fruit \\
\hline Spondias & dulcis & Anacardaceae & tree & fruit \\
\hline Syzygium & aneityensis & Myrtaceae & tree & fruit \\
\hline Syzygium & buettnerianum & Myrtaceze & tree & fruit \\
\hline Syzygium & clusizefolium & Myrtaceae & tree & fruit \\
\hline Syzygium & cuminii & Myrtaceae & tree & fruit \\
\hline Syzygium & effusum & Myrtaceəe & tree & fruit \\
\hline Syzygium & gracilipes & Myrtaceze & tree & fruit \\
\hline Syzygium & kajewskii & Myrtaceae & tree & fruit \\
\hline Syzygium & malaccense & Myrtaceae & tree & fruit \\
\hline Syzygium & myriadenum & Myrtaceae & tree & fruit \\
\hline Syzygium & near.s.nomoa & Myrtaceze & tree & fruit \\
\hline Syzygium & пеераи & Myrtaceae & tree & fruit \\
\hline Syzygium & nidie & Myrtaceae & tree & fruit \\
\hline Syzygium & nотод & Myrtaceəe & tree & fruit \\
\hline Syzygium & richii & Myrtaceae & tree & fruit \\
\hline Morinda & citrifolia & Rubiaceae & shrub & fruit and young leaves \\
\hline Calamus & rotana & Aгесасеае & palm & heart \\
\hline Calamus & vanuatensis & Arecaceae & palm & heart \\
\hline Caryota & ophiopellis & Arecaceas & palm & heart \\
\hline Caryota & Sp. & Arecaceae & palm & heart \\
\hline Clinostigma & harlandii & Arecaceae & palm & heart \\
\hline Clinostigma & Sp. & Arecaceae & palm & heart \\
\hline $\operatorname{cocos}$ & nucifera & Arecaceae & palm & heart and fruit \\
\hline
\end{tabular}




\begin{tabular}{|c|c|c|c|c|}
\hline Genus & Species & Family & Type & Main part consumed \\
\hline Kajewskia & aneityensis & Arecaceae & palm & heart \\
\hline Licuala & grandis & Arecaceae & palm & heart \\
\hline Licuala & Sp. & Arecaceae & palm & heart \\
\hline Metroxylon & warburgii & Arecaceae & palm & heart \\
\hline Veitchia & macdanielsii & Arecaceae & palm & heart \\
\hline Veitchia & arecina & Arecaceae & palm & heart \\
\hline Veitchia & metiti & Arecaceae & palm & heart \\
\hline Veitchia & $s p$ & Arecaceae & palm & heart \\
\hline Veitchia & spiralis & Arecaceae & palm & heart \\
\hline Veitchia & winin & Arecaceae & palm & heart \\
\hline Gulubia & cylindrocarра & Arecaceae & palm & heart \\
\hline Pritchardia & pacifica & Arecaceae & palm & heart \\
\hline Geniostoma & rupestre & Gesneriaceae & tree & leaves \\
\hline Pisonia & grandis & Nyctaginaceae & tree & leaves \\
\hline Polyscias & sp. & Araliaceae & tree & leaves \\
\hline Cyclosorus & spp. & Thelypteridaceae & fern & leaves \\
\hline Dennstaedtia & samoensis & Dennestediaceae & fern & leaves \\
\hline Diplazium & spp. & Tectariaceae & fern & leaves \\
\hline Polyscias & cissodendron & Araliaceae & tree & leaves \\
\hline Polyscias & scuttelaria & Araliaceae & tree & leaves \\
\hline Polyscias & samoensis & Araliaceae & tree & leaves \\
\hline Graptophyllum & pictum & Acanthaceae & tree & leaves \\
\hline Rhizophora & apiculata & Rhizophoraceae & tree & leaves \\
\hline Cyathea & spp. & Cyatheaceae & fern & leaves \\
\hline Blechnum & procerum & Blecnaceae & fern & leaves \\
\hline Wollastonia & biflora & Asteraceae & shrub & leaves \\
\hline Adenanthera & pavonina & Fabaceae & tree & nut \\
\hline Pangium & edule & Flacourtiaceae & tree & nut \\
\hline Sterculia & \begin{tabular}{|l} 
vitiensis \\
\end{tabular} & Sterculiaceae & tree & nut \\
\hline Gnetum & gnemon & Gnetaceae & tree & nut \\
\hline Inocarpus & fagifer & Fabaceae & tree & nut \\
\hline Aleurites & moluccana & Euphorbiaceae & tree & nut \\
\hline Barringtonia & edulis & Lecythidaceae & tree & nut \\
\hline Barringtonia & ргосега & Lecythidaceae & tree & nut \\
\hline Barringtonia & racemosa & Lecythidaceae & tree & nut \\
\hline Barringtonia & sp. & Lecythidaceae & tree & nut \\
\hline Canarium & aneityensis & Burseraceae & tree & nut \\
\hline Canarium & harveyi & Burseraceae & tree & nut \\
\hline Canarium & indicum & Burseraceae & tree & nut \\
\hline Canarium & sp. & Burseraceae & tree & nut \\
\hline Canarium & vitiense & Burseraceae & tree & nut \\
\hline Cordia & subcordata & Boraginaceae & tree & nut \\
\hline Terminalia & catappa & Combretaceae & tree & nut \\
\hline Terminalia & samoensis & Combretaceae & tree & nut \\
\hline Terminalia & sepicana & Combretaceae & tree & nut \\
\hline Terminalia & Sp. & Combretaceae & tree & nut \\
\hline Myristica & sp. & Myristicaceae & tree & nut \\
\hline Dioscorea & bulbifera & Dioscoreaceae & vine & tuber \\
\hline Dioscorea & nummularia & Dioscoreaceae & vine & tuber \\
\hline Dioscorea & pentaphylla & Dioscoreaceae & vine & tuber \\
\hline
\end{tabular}




\begin{tabular}{|l|l|l|l|l|}
\hline Genus & Species & Family & Type & Main part consumed* \\
\hline Pueraria & lobata & Fabaceae & vine & tuber \\
\hline Tacca & leontopetaloides & Taccaceae & herb & tuber \\
\hline Freicynetia & sp. & Pandanaceae & pandanus & young inflorescences \\
\hline Freycinetia & impavida & Pandanaceae & pandanus & young inflorescences \\
\hline Freycinetia & microdonnta & Pandanaceae & pandanus & young inflorescences \\
\hline Freycinetia & nombsorii & Pandanaceae & pandanus & young inflorescences \\
\hline Freycinetia & reineckei & Pandanaceae & pandanus & young inflorescences \\
\hline Freycinetia & sp. & Pandanaceae & pandanus & young inflorescences \\
\hline Freycinetia & tannaensis & Pandanaceae & pandanus & young inflorescences \\
\hline Freycinetia & wilderi & Pandanaceae & pandanus & young inflorescences \\
\hline Pandanus & cominsii & Pandanaceae & pandanus & young inflorescences \\
\hline Laportea & spp. & Urticaceae & tree & young leaves \\
\hline
\end{tabular}

The list is not exhaustive but includes species that are easily accessible, tasty and readily consumable with minimum effort.

"different parts of the plants are edible: hearts, fruit, leaves, tuber.

Source: Authors' summary of data.

\section{Discussion}

The large islands of Vanuatu (Santo, Malakula, Efate) are considered to be approximately 14-20 million years old (Hamilton et al. 2010). As the archipelago is quite close (between $1000-2000 \mathrm{~km}$ ) to floristically rich continental sources (Solomons, Fiji, New Caledonia), plant colonisation via natural means was a fairly straightforward and easy process over such a long period of time (several million years). The first descriptions of the islands made by Quiros, Bougainville, Cook and others, insist on the rich and dense flora, still there after 2700 years or so of colonisation by humans. Despite 3000 years of successive waves of invasion by predators (humans, pigs, dogs and rats), numerous edible wild plant species still exist today and are found throughout the Vanuatu archipelago. They represent approximately 10 per cent of the total number of native species of 1166 taxa and are reliable sources of healthy food in times of scarcity, and often used by the local communities to diversify their diets. Many of these species, or related ones, also exist in the northern part of Melanesia. It is, therefore, possible that they were easily recognised by the first migrants who foraged and gathered food from the Vanuatu forests while waiting to build up a stock of staple crops vegetatively (greater yam, taro and bananas). In fact, the native flora may have been richer than it is today. For example, pollen records, dated 3900-3790 cal. BP, are available from a site nearby the Teouma Lapita site (Emaotfer swamp) on Efate (Combettes et al. 2015). This palynological analysis recorded pollen of Podocarpus sp., but today it is impossible to find the species on Efate and it is restricted to the northern part of the archipelago.

It has been shown that the first settlers' Lapita Cultural Complex included horticulture of vegetatively introduced crops (Horrocks and Bedford 2005, 2010; Horrocks et al. 2009). However, in a climatically variable environment such as the South-West Pacific (Lebot 2013), vegeculture must be combined with fruit and nut gathering to diversify diets. Staple crops provide mostly carbohydrates while ferns, green young leaves, fleshy fruits and nuts represent foods rich in proteins, lipids and/or vitamins and essential minerals. However, there is also a cropping system rationale to associate plants vegetatively propagated (with no tap root and a superficial rooting system) to trees that protect them from winds and drought and provide the necessary buffers to plot microclimate variation. Therefore, the traditional systems had to establish small plots of vegetatively propagated crops and to surround them with tall trees. Arboriculture is the necessary technical complement of vegeculture or the latter will fail. 
In Vanuatu, the numerous indigenous wild fruit and nut tree species have been domesticated (and still are in many cases) following a simple straightforward process. When a wild productive morphotype is identified in the forest, the fruits and nuts are tested and if the quality is acceptable, a seedling found under the mother tree is collected and planted closer to the community settlement. Unlike the wild mother plant, the seedling is usually planted in well-tended and improved environment that favours its establishment and growth contributing to the ennobled development of the selected wild genotype. Over the long term, the continuous selection has led to the improvement of local wild species but gene flows between selected and wild forms continue, and most useful tree species are still very diverse. We cannot yet observe a reduction of the genetic base (Lebot et al. 2007).

Species evolution in an environment almost free of natural predators has considerably limited the number of species that need to accumulate toxins to protect themselves from potential damage. Many plants are therefore edible in their fresh and raw form and do not necessitate detoxification via cooking. However, the availability of local cooking containers (Bambusa vulgaris) or Licuala grandis leaves could have increased the number of wild edible species. Bambusa vulgaris rhizomes are very large and are often eroded from riverbanks and found drifting away in the ocean. They can colonise isolated islands by natural means and the natural bamboo forests found today on the west coast of Santo have all the attributes of a native, indigenous species. If this resource was readily available, it obviously represented a practical means of having access, after cooking, to numerous native edible species.

In this chapter, we have attempted to show that there were several good edible plants in Vanuatu prior to human colonisation, the most diverse ones were certainly the palms (including the coconut), the figs and many other fruit and nut species, ferns and wild yams. Although Vanuatu was not a 'green desert', as has been earlier proposed, recent studies do indicate that Lapita colonisers could have focused overwhelmingly on the most easily accessible and very abundant terrestrial animal and marine resources rather than exploiting the edible local flora. However, there is no reason to believe that the diminution of plant species from Near to Remote Oceania could have been a factor restricting human colonisation of the area during the Pleistocene.

\section{References}

Bedford, S. 2006. Pieces of the Vanuatu puzzle: Archaeology of the north, south and centre. Terra Australis 23. Pandanus Books, The Australian National University, Canberra. doi.org/10.22459/PVP.02.2007.

Buckley, H., R. Kinaston, S.E. Halcrow, A. Foster, M. Spriggs and S. Bedford 2014. Scurvy in a tropical paradise? Evaluating the possibility of infant and adult vitamin C deficiency in the Lapita skeletal sample of Teouma, Vanuatu, Pacific Islands. International Journal of Paleopathology 5:72-85. doi.org/ 10.1016/j.ijpp.2014.03.001.

Carney, J.N., A. MacFarlane and D. Mallick 1985. The Vanuatu Island arc: An outline of the stratigraphy, structure and petrology. In A. Nairn, F.G. Stehli and S. Uyeda (eds), The ocean basin and marginsThe Pacific Ocean 7a:685-718. Plenum Press, New York. doi.org/10.1007/978-1-4613-2351-8_14.

Combettes, C., A.-M. Sémah and D. Wirrmann 2015. High-resolution pollen record from Efate Island, central Vanuatu: Highlighting climatic and human influences on Late Holocene vegetation dynamics. Comptes Rendus Palevol 14:251-261. doi.org/10.1016/j.crpv.2015.02.003.

English, R.M, W. Aalbersberg and P. Scheelings 1996. Pacific Island foods: Description and nutrient composition of 78 local foods. ACIAR project 9306, IAS technical report 96/02. University of the South Pacific, Suva, Fiji. 
Fosberg, F.R. 1984. Phytogeographic comparison of Polynesia and Micronesia. In F.J. Radovsky, P.H. Raven and S.H. Sohmer (eds), Biogeography of the Tropical Pacific, pp. 33-44. Bernice P. Bishop Museum, Hawaii.

Green, R.C. 1991. Near and Remote Oceania: Disestablishing 'Melanesia' in culture history. In A. Pawley (ed.), Man and a half: Essays in Pacific anthropology and ethnobiology in honour of Ralph Bulmer, pp. 491-502. The Polynesian Society, Auckland.

Greene, H.G. and F.L. Wong (eds) 1988. Geology and offshore resources of Pacific Islands Arcs-Vanuatu Region. Earth Sciences Series 8. Circum-Pacific Council for Energy and Mineral Resources, Houston, Texas.

Hamilton, A.M., E.R. Klein and C. Austin 2010. Biogeographic breaks in Vanuatu, a nascent Oceanic archipelago. Pacific Science 64:149-159. doi.org/10.2984/64.2.149.

Horrocks, M. and S. Bedford 2005. Microfossil analysis of Lapita deposits in Vanuatu reveals introduced Araceae (aroids). Archaeology in Oceania 40:67-74. doi.org/10.1002/j.1834-4453.2005.tb00587.x.

Horrocks, M. and S. Bedford 2010. Introduced Dioscorea spp. starch in Lapita and later deposits, Vao Island, Vanuatu. New Zealand Journal of Botany 48(3-4):179-183. doi.org/10.1080/0028825X. 2010.502238 .

Horrocks, M., S. Bedford and M. Spriggs 2009. A short note on banana (Musa) phytoliths in Lapita, immediately Post-Lapita and modern period archaeological deposits from Vanuatu. Journal of Archaeological Science 36:2048-2054. doi.org/10.1016/j.jas.2009.05.024.

Keppel, G., A. Lowe and H. Possingham 2009. Changing perspectives on the biogeography of the Tropical South Pacific: Influences of dispersal, vicariance and extinction. Journal of Biogeography 36:1035-1054. doi.org/10.1111/j.1365-2699.2009.02095.x.

Kinaston, R., H. Buckley, F. Valentin, S. Bedford, M. Spriggs, S. Hawkins and E. Herrscher 2014. Lapita diet in Remote Oceania: New stable isotope evidence from the 3000-year-old Teouma site, Efate Island, Vanuatu. PLoS ONE 9(3):e90376. doi.org/10.1371/journal.pone.0090376.

Kreike, C., H.J. van Eck and V. Lebot 2004. Genetic diversity of taro, Colocasia esculenta (L.) Schott, in Southeast Asia and the Pacific. Theoretical and Applied Genetics 109:761-768. doi.org/10.1007/ s00122-004-1691-z.

Lebot, V. 1992. Genetic vulnerability of Oceania's traditional crops. Experimental Agriculture 28(3):309323. doi.org/10.1017/S0014479700019906.

Lebot, V. 1999. Biomolecular evidence for plant domestication in Sahul. Genetic Resources and Crop Evolution 46(6):619-628. doi.org/10.1023/A:1008748504038.

Lebot, V. 2013. Coping with insularity: The need for crop genetic improvement to strengthen adaptation to climatic change and food security in the Pacific. Environment, Development and Sustainability 15(6):1405-1423. doi.org/10.1007/s10668-013-9445-1.

Lebot, V., M. Aradhya, R. Manshardt and B. Meilleur. 1993. Genetic relationships among cultivated bananas and plantains from Asia and the Pacific. Euphytica 67(3):163-175. doi.org/10.1007/ BF00040618.

Lebot, V., B. Trilles, J.L. Noyer and J. Modesto 1998. Genetic relationships between Dioscorea alata L. cultivars. Genetic Resources and Crop Evolution 45(6):499-509. doi.org/10.1023/A:1008603303314.

Lebot, V., T. Gunua, J.R. Pardales, M.S. Prana, M. Thongjiem, N.V. Viet and T.C. Yap 2004. Characterisation of taro (Colocasia esculenta (L.) Schott) genetic resources in Southeast Asia and Oceania. Genetic Resources and Crop Evolution 51:381-392. doi.org/10.1023/B:GRES.0000023453. 30948.4d. 
Lebot, V., A. Walter and C. Sam 2007. The domestication of fruit and nut tree species in Vanuatu. In F.K. Akinnifesi, R.R.B. Leakey, O.C. Ajaui, G. Sileshi, Z. Tchoundjeu, P. Matakala and F.R. Kwesiga (eds), Indigenous fruit trees in the tropics: Domestication, utilization and commercialization, pp. 120-136. CABI Publishing, Oxfordshire. doi.org/10.1079/9781845931100.0120.

Malapa, R., G. Arnau, J.L. Noyer and V. Lebot 2005. Genetic diversity of the greater yam (Dioscorea alata L.) and relatedness to $D$. nummularia Lam. and D. transversa $\mathrm{Br}$. as revealed with AFLP markers. Genetic Resources and Crop Evolution 52(7):919-929. doi.org/10.1007/s10722-003-6122-5.

McClatchey, W.C. 2012. Wild food plants of Remote Oceania. Acta Societatis Botanicorum Poloniae 81(4):371-380. doi.org/10.5586/asbp.2012.034.

Monzier, M., C. Robin, J.-P. Eissen and J. Cotton 1997. Geochemistry vs seismo-tectonics along the volcanic New Hebrides Central Chain (Southwest Pacific). Journal of Volcanology and Geothermal Research 18:1-29. doi.org/10.1016/S0377-0273(97)00006-1.

Mueller-Dombois, D. and F.R. Fosberg 1998. Vegetation of the Tropical Pacific Islands. Springer, New York. doi.org/10.1007/978-1-4419-8686-3.

Payri, C. 2011. Benthic algal and seagrass communities from Santo Island in relation to habitat diversity. In P. Bouchet, H. Le Guyader and O. Pascal (eds), The natural history of Santo, pp. 337-368. MNHN, IRD, Paris.

Petchey, F., M. Spriggs, S. Bedford, F. Valentin and H.R. Buckley 2014. Radiocarbon dating of burials from the Teouma Lapita cemetery, Efate, Vanuatu. Journal of Archaeological Science 50:227-242. doi.org/ 10.1016/j.jas.2014.07.002.

Sardos, J., J.L. Noyer, R. Malapa, S. Bouchet and V. Lebot 2012. Genetic diversity of taro (Colocasia esculenta (L.) Schott) in Vanuatu (Oceania): An appraisal of the distribution of allelic diversity (DAD) with SSR markers. Genetic Resources and Crop Evolution 59:805-820. doi.org/10.1007/s10722-0119720-7.

Spriggs, M. 1984. Early coconut remains from the South Pacific. The Journal of the Polynesian Society 93(1):71-76.

Spriggs, M. 1997. The Island Melanesians. Blackwell, Oxford.

VandenBroucke H., P. Mournet, H. Vignes, H. Chaïr, R. Malapa, M.F. Duval and V. Lebot 2016. Somaclonal variants of taro (Colocasia esculenta Schott) and yam (Dioscorea alata L.) are incorporated into farmers' varietal portfolios in Vanuatu. Genetic Resources and Crop Evolution 63:495-511. doi.org/ 10.1007/s10722-015-0267-x.

Walter, A. and V. Lebot 2007. Gardens of Oceania. ACIAR Monograph No. 122, Canberra.

Wheatley, J.L. 1992. A guide to the common trees of Vanuatu, with list of their traditional uses and $\mathrm{Ni}$-Vanuatu names. Department of Forestry, Port Vila.

Whistler, W.A. 2009. Plants of the Canoe People: An ethnobotanical voyage through Polynesia. National Tropical Botanical Garden, Hawai i.

White, A., T. Worthy, S. Hawkins, S. Bedford and M. Spriggs 2010. Megafaunal meiolaniid horned turtles survived until early human settlement in Vanuatu, Southwest Pacific. Proceedings of the National Academy of Sciences 107:15512-15516. doi.org/10.1073/pnas.1005780107.

Worthy, T.H., S. Hawkins, S. Bedford and M. Spriggs 2015. Avifauna from the Teouma Lapita site, Efate Island, Vanuatu, including a New Genus and Species of Megapode. Pacific Science 69(2):205-254. doi.org/10.2984/69.2.6.

Yen, D.E. 1974. Arboriculture in the subsistence of Santa Cruz, Solomon Islands. Economic Botany 28:247-284. doi.org/10.1007/BF02861424. 
This text is taken from Debating Lapita: Distribution, Chronology, Society and Subsistence, edited by Stuart Bedford and Matthew Spriggs, published 2019 by ANU Press,

The Australian National University, Canberra, Australia.

doi.org/10.22459/TA52.2019.19 